\section{Cultivation of human embryonic liver cells in disposable microplates}

MARIE A. BRYCESON, PATRICIA E. TAYLOR, AND A. J. ZUCKERMAN From the Department of Bacteriology and Immunology, The London School of Hygiene and Tropical Medicine, London

Zuckerman, Tsiquaye, and Fulton in 1967 described a method for the cultivation of monolayers of differentiated parenchymal human embryonic liver cells in glass tissue culture plates made especially for this purpose. The apparatus utilized and the precise method of implantation are given in detail by Fulton (1960). This technique was later modified and extended to the culture of very small fragments of human adult liver obtained by needle biopsy for diagnostic purposes (Taylor, Zuckerman, and Farrow, 1970). The present communication describes the adaptation of these methods to the growth of human embryonic liver cells in commercially available disposable plastic microplates and the need to manufacture special glass tissue culture vessels is thus eliminated. This adaptation also facilitates the cultivation of tissue when only very limited amounts are available and renders the method more suitable for wide-scale use by utilizing readily available apparatus.

Human embryo livers 8 to 16 weeks old were obtained from the Tissue Bank of the Royal Marsden Hospital and a suspension of cells was prepared by disaggregation of the tissue for 10 minutes in $0.2 \%$ trypsin (Zuckerman et al, 1967b). Four cycles of trypsinization were utilized. Dispersed cells were removed after each cycle and kept at $4^{\circ} \mathrm{C}$ until trypsinization was complete. The trypsin was inactivated with $20 \%$ calf serum and a pellet of cells obtained by centrifugation at $700 \mathrm{rpm}$ for five Received for publication 27 July 1971.

A quick method for the isolation of glomeruli from human kidney-continued

fluorescent localisation of globulin deposits in relation to human glomerular basement membranes. Brit. J. exp. Path., 49, 272-276.

Krakower, C. A., and Greenspon, S. A. (1951). Localisation of nephrotoxic antigen within isolated renal glomerulus. Arch. Path., 51, 629-639.

Lannigan, R., Barabas, A. Z., Peters, K., and Hardwicke, J. (1969). Some experimental models of the nephrotic syndrome. Meth. Achiev. exp. Path., 4, 141-170.

Nagasawa, T., and Shibata, S. (1970). Application of the antibody against soluble GBM substance to the immunofluorescence staining of kidney sections. Japan J. exp. Med., 40, 23-32.

Spiro, R. G. (1966). Studies on the renal glomerular basement membrane. J. biol. Chem., 242, 1915-1922. minutes. Cells were washed once in growth medium consisting of Eagle's minimum essential medium p 7.2 containing $10 \%$ foetal calf serum, 100 units penicillin per $\mathrm{ml}, 100 \mu \mathrm{g}$ streptomycin per $\mathrm{ml}$, and 50 units nystatin per $\mathrm{ml}$.

Modifications of the equipment and methods described by Fulton (1960) consist of the use of Perspex plates approximately 1 in. square with nine divisions, and disposable Falcon plastic microtest plates which contain 60 wells and come already sterilized with an easily manipulated lid. Discs, $3.5 \mathrm{~mm}$ in diameter, were cut from polythene film ${ }^{1}$, 150 gauge $(0.0015$ in.) using a metal punch. The diameter of the discs was slightly smaller than that of the wells. The cells were implanted on the sterilized polythene using clotted mouse plasma as an adhesive. After implantation, excess fluid was not removed from beneath the discs by inverting the Perspex plate on top of sterilized filter paper and applying gentle pressure to it, because it was found that any pressure exerted on the disc resulted in injury to the cells. Instead, the Perspex plates were simply allowed to

${ }^{1}$ British Visqueen Ltd, Herts, England

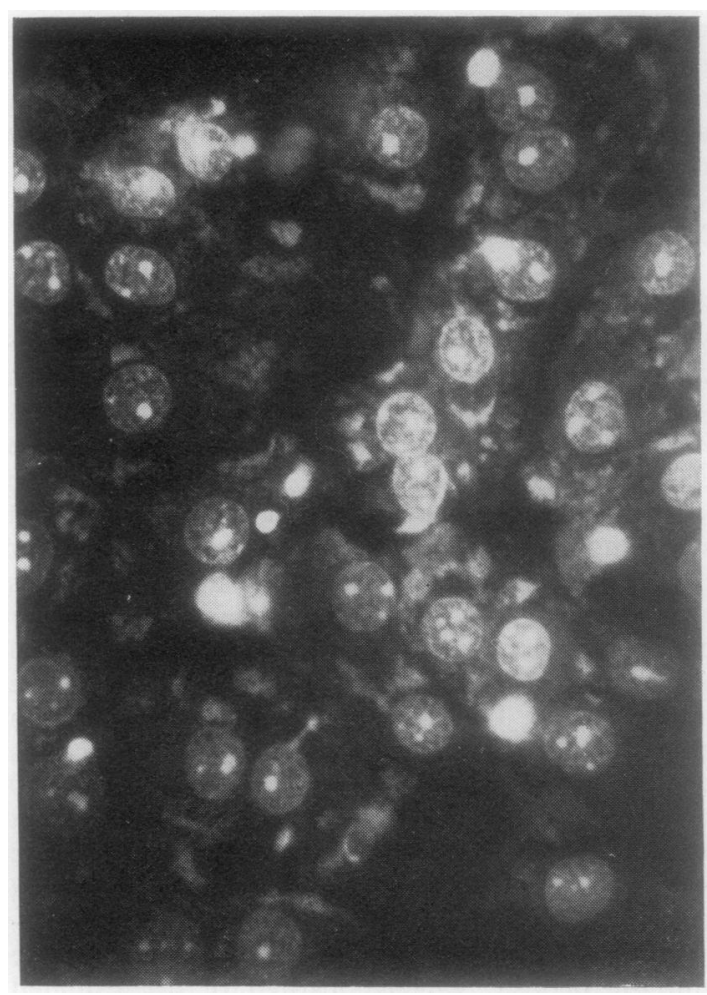

Fig. 1 The typical appearance of human embryo hepatocytes after four days in culture $\times 900$. 


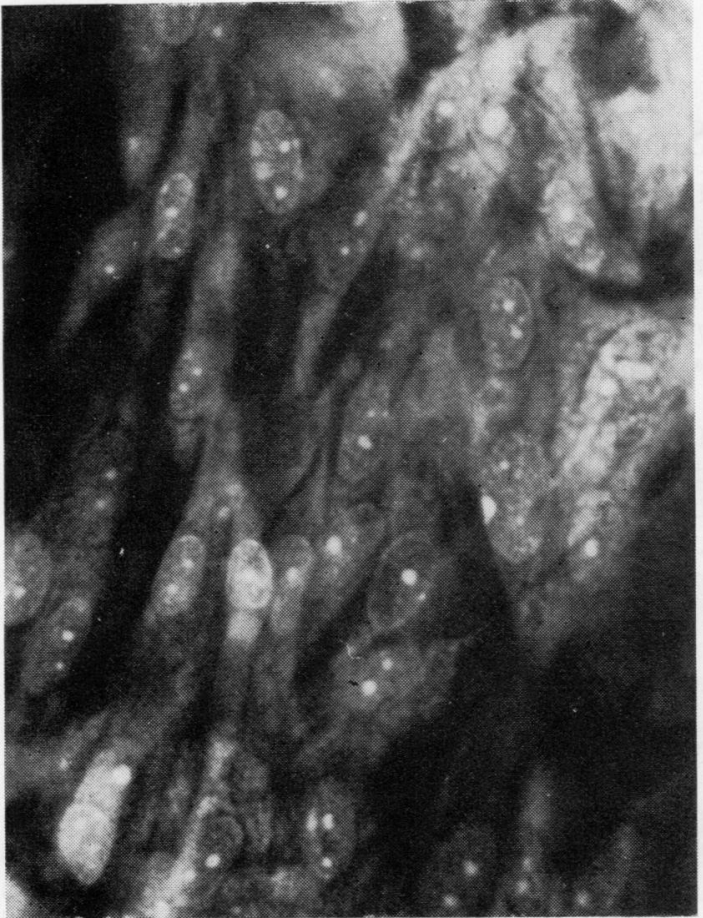

Fig. 2 After 10 days in culture overgrowth by spindleshaped cells is frequent $\times 900$.

remain in a sterile covered Petri dish until the clotting of the plasma was complete. The discs with adhered cells were then removed and floated on $0.025 \mathrm{ml}$ of growth medium with the dry surface of the polythene uppermost. Cultures were incubated at $35^{\circ} \mathrm{C}$ in an atmosphere containing $2 \% \mathrm{CO}_{2}$.

Adenovirus type 3 which had had two passages in a semi-continuous human embryonic liver cell line (Zuckerman, Taylor, Jacobs, and Jones, 1970) was used to determine whether the susceptibility of cells prepared in this way was equivalent to that of cells prepared by the original and more complex method described by Zuckerman et al (1967b). In these latter cultures the TCID ${ }_{50}$ of the stock suspension of virus was $10^{-3.5}$ per $0.1 \mathrm{ml}$. The stock virus was titrated in the microdisc cultures by inoculating $0.01 \mathrm{ml}$ of serial 10 -fold dilutions made up in growth medium. The titre of the virus suspension was found to be approximately the same as that obtained by cells grown in the special glass vessels.

Periodic examination of the cultures was made by inverting the plate and viewing the cells through the medium contained in the well with a light microscope, an added advantage of this new technique.

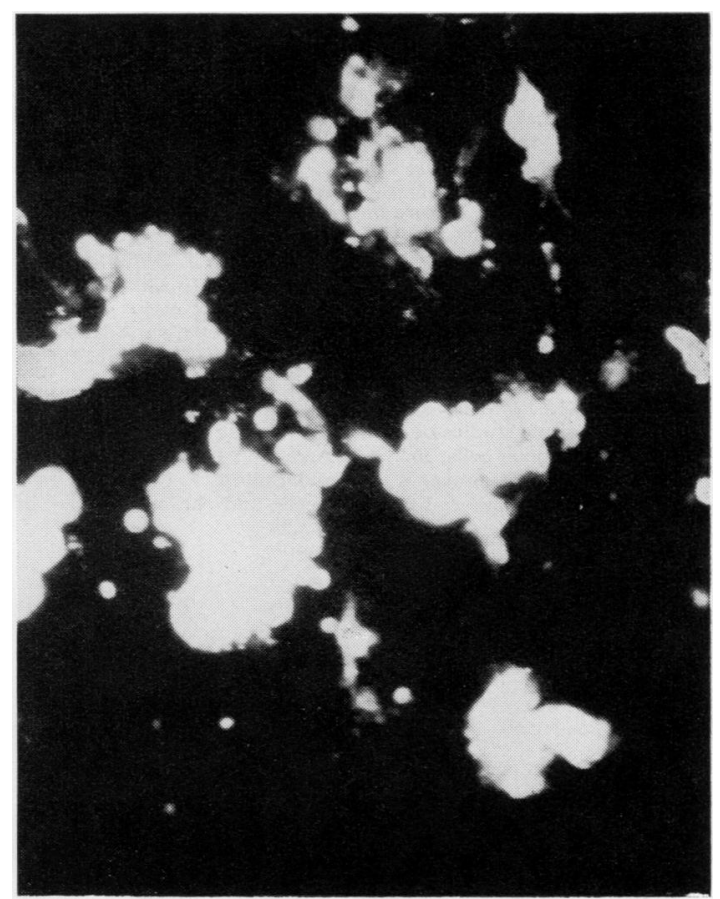

Fig. 3 Advanced cytopathogenic changes induced by adenovirus type 3. The cell sheet is completely disrupted and the cells are in an advanced state of degeneration $\times 900$.

The cultured cells were stained with $1 / 1000$ (W/V) solution of acridine orange in acetate veronal buffer $p \mathbf{H} 4 \cdot 2$ for study by fluorescence microscopy.

Monolayers of cells were established on the microdiscs within three to four days after implantation. Polygonal-shaped, epithelial-like cells with the appearance of hepatocytes predominated. These could be maintained for up to eight days (Fig. 1). After this time, there was a predominance of spindleshaped, fibroblast-like cells (Fig. 2). Optimal conditions for the maintenance of these cultures were attained when the growth medium was replaced by fresh medium every two to three days.

Twenty-four hours after inoculation of the microdisc cultures with the $10^{-1}$ dilution of stock adenovirus type 3 , a cytopathogenic effect was noted in the nucleus of scattered parenchymal cells. This progressed until there was total involvement of the monolayer four days after inoculation. The cytopathogenic effect observed was typical of adenovirus type 3 infection in human embryonic liver cells as described by Zuckerman, Alwen, and Fulton (1967a) (Fig. 3). The TCID $_{50}$ of the stock virus suspension in the microdisc cultures was $10^{-3.6}$. 
We are grateful to Dr H. E. M. Kay of the Royal Marsden Hospital for the continuing supply of foetal tissue.

\section{References}

Fulton, F. (1960). Tissue culture on polythene. J. gen. Microbiol., 22, 416-422.

Taylor, P. E., Zuckerman, A. J., and Farrow, L. J. (1969). Culture of needle biopsies of the liver from patients with suspected hepatitis. J. clin. Path., 22, 701-703.

Zuckerman, A. J., Alwen, J., and Fulton, F. (1967a). Adenovirus infection of human embryo liver cells. Nature (Lond.), 214, 606608.

Zuckerman, A. J., Taylor, P. E., Jacobs, J. P., and Jones, C. A. (1970). Chromosome studies of virus infected semi-continuous human embryonic liver cells. Brit. J. exp. Path., 51, 92-96.

Zuckerman, A. J., Tsiquaye, K. N., and Fulton, F. (1967b). Tissue culture of human embryo liver cells and the cytotoxicity of aflatoxin B. Brit. J. exp. Path., 48, 20-27.

\section{Storage of lymphocytes for immunological study}

T. M. BELL, E. A. CASPARY, AND E. J. FIELD From the Medical Research Council Demyelinating Diseases Unit, Newcastle General Hospital, Westgate Road, Newcastle upon Tyne

It not uncommonly happens that tests of lymphocyte responsiveness to antigens cannot be carried out immediately so that a simple means of storage is useful. This is especially the case with the electrophoresis method described by Field and Caspary (1970) where unpredictable vagaries of the instrument add to the pressure of numbers. Simple procedures are described to allow testing to be delayed.

\section{Method}

Lymphocytes were separated from fresh venous blood by the modification introduced by Hughes and Caspary (1970) of the method devised by Coulson and Chalmers (1967). The method utilizes carbonyl iron and methyl cellulose and gives yields of approximately $10^{6}$ lymphocytes per ml blood, $95-98 \%$ small and almost $100 \%$ viable (as shown by a dye exclusion test). During the preparation serum is separated and preserved.

If the lymphocytes are to be used within 72 hours they can be kept at $4^{\circ} \mathrm{C}$ with the addition of $10 \%$ of the patient's own serum to the final 199 medium. Before use they are washed and resuspended in 199, care being taken not to exceed $250 \mathrm{~g}$ in centrifugation.

If, on the other hand, the cells cannot be used within this time, then they may be stored in liquid nitrogen for at least a month without demonstrable loss of immunological activity as studied by the cell electrophoresis method.

To do this, lymphocytes in medium 199 are spun down and resuspended to a concentration of $3 \times 10^{6}$ per $\mathrm{ml}$ in freezing medium. This comprises $80 \%$ Hank's BSS containing $\mathbf{0 . 5 \%}$ lactalbumin hydrolysate (MRC Central Stores) and 20\% calf serum (Oxoid), buffered to approximately $p \mathrm{H} 7.2$ with $0.035 \%$ sodium bicarbonate. This medium is stable at $4^{\circ} \mathrm{C}$ for up to one month. Immediately before use $10 \%$ dimethyl sulphoxide $(\mathrm{BDH})$ is added. In this medium cells may be left up to 24 hours at $4^{\circ} \mathrm{C}$. Usually they are dispensed in $1.0 \mathrm{ml}$ hard glass ampoules (Johnsen and Jorgensen) labelled and then heat sealed. These ampoules are left at $4^{\circ} \mathrm{C}$ for a Received for publication 14 October 1971. 